\title{
Smoking and health: the association between smoking behaviour, total mortality, and cardiorespiratory disease in west central Scotland
}

\author{
V. M. HAWTHORNE \\ From the Department of Epidemiology, University of Michigan
}

J. S. FRY

From the Department of Statistics, University of Glasgow

SUMMARY The relationship of smoking to total mortality and to the prevalence of cardiorespiratory symptoms has been studied in three prospective surveys in west central Scotland in which 18786 people attended a multiphasic screening examination. The prevalence of respiratory symptoms, and to a lesser extent cardiovascular symptoms, increased with the number of cigarettes smoked, with inhalation, and with a younger age of starting to smoke. A lower prevalence of respiratory symptoms in both sexes was observed in smokers of filter cigarettes than in smokers of plain cigarettes, and in those who smoked cigarettes with lower tar levels, irrespective of whether these were filtered or plain. In general, the relationships found between smoking and mortality were similar to those reported by other workers. Current cigarette smokers had a death rate from all causes which was twice that of those who had never smoked. No difference was found between the mortality rates of smokers of plain and filter cigarettes.

Numerous prospective studies have investigated the relationship between smoking and mortality (Royal College of Physicians, 1977). However, most of them relate to special groups of the population, such as doctors (Doll and Peto, 1976) or life insurance policy holders (Kahn, 1966), and many relate to countries outside the United Kingdom. Indeed, so far as we are aware, apart from the 12.4 year follow-up of the British population random sample reported elsewhere in this issue (Todd et al., 1978), no prospective mortality study of a 'typical' population has previously been reported in the United Kingdom. Information is also scarce on the relationship that recent marketing changes in the type of cigarette may have had with mortality from smoking-associated disease. Apart from the previously mentioned study and the retrospective study carried out in north east England (Dean et al., 1977), no information based on United Kingdom data has previously been published on the relative associations of filter and plain smoking with mortality.

\section{Methods}

Since 1965, in collaboration with the late Professor
D. D. Reid, the Mass Health Examination Unit of the Greater Glasgow Health Board has been carrying out examinations of both general populations and occupational groups. The main objectives of this paper are, firstly, to analyse the relationship between various aspects of smoking behaviour and subsequent mortality, and, secondly, to study the relationship between smoking and cardiorespiratory symptoms.

Three separate surveys were undertaken in west central Scotland, where the prevalence of cardiorespiratory mortality has been recognised as the highest in western Europe (Fulton et al., 1978). The first two studies, which took place between 1965 and 1968 (Survey 1), and between 1970 and 1972 (Survey 2), were predominantly of persons examined in occupational groups (Hawthorne et al., 1972), but they included also the censusidentified population of the Scottish island of Tiree (Hawthorne et al., 1969). Together these studies included 5694 men and 815 women. The third study, between 1974 and 1975 (Survey 3), of 5601 men and 6676 women, was confined to the census-identified population of Paisley (Hawthorne et al., 1975). The overall response rate averaged $77 \%$. 
The full examination procedure has been described before (Hawthorne et al., 1969). For the purpose of this paper it is only necessary to know that the subject first completed a questionnaire on smoking and cardiorespiratory symptoms, which was then checked for missing information.

Information on subsequent mortality was obtained through the National Health Service Central Register at Edinburgh.

The present paper confines itself to those aged 45 to 64 at examination and restricts attention to the following variables:

\section{SMOKING}

Smokers were classified into three groups: current smokers, ex-smokers, or never smoked. The current smokers were classified by the number of cigarettes a day currently smoked, the type of cigarette normally smoked (filter, plain or hand-rolled), whether or not the smokers said that they inhaled, the age of starting to smoke, and (except in Survey 2) the brand of cigarette smoked. An individual was considered a smoker only if he smoked five or more cigarettes a day. The tar levels of the various brands were supplied by the Tobacco Research Council.

\section{CARDIORESPIRATORY SYMPTOMS}

The MRC bronchitis questionnaire (Medical Research Council, 1966) was used and the responses classified according to the presence of bronchitis syndrome, shortness of breath, wheezing, and persistent phlegm as defined in the questionnaire; the responses on angina and possible infarction were classified as defined by Rose and Blackburn (1968).

\section{MORTALITY}

All deaths reported between the time of examination and 31 October 1977 were classified into the following cause of death groups; ischaemic heart disease (ICD codes 410-414), cerebrovascular disease (430-438), lung cancer (162-1), chronic bronchitis (490-493), infectious and other respiratory diseases (460-486 and 510-519) (World Health Organisation, 1967) and all other causes.

\section{Statistical Methods}

The significance of an association between a factor (such as the age of starting to smoke) and the presence or absence of a symptom (such as angina), standardised for one or more confounding variables (such as age and number of cigarettes smoked), was evaluated using the following technique, based on that described by Peto and Pike (1973).

The data were first divided into strata according to combinations of the confounding variables; then these strata were subdivided into levels according to a factor. Within a stratum, at the $\mathrm{j}^{\mathrm{jt}}$ level of a factor, 0 , was the number observed with the symptom and $S_{1}$ the number studied at that level. Assuming that the factor is independent of the prevalence of symptoms, the expected number, $E_{j}$, with the symptom within the stratum was calculated, and hence the deviation, $D_{j}$, from expectation.

$$
\text { Where } D_{j}=0_{j}-E_{j}
$$

These were then summed over all strata. The deviations were then tested for significant departure from the null hypothesis by assuming that

$$
\chi^{2}=d \cdot A^{-1} d
$$

is asymptomatically distributed as $\chi^{2}$ with $\mathrm{m}-1$ degrees of freedom. [Where $\mathrm{m}$ is the number of levels of the factor, $d$ is the vector formed by the first m-1 total deviations and $A$ is their covariance matrix (Peto and Pike, 1973).] Particular levels may be tested for deviation from the null hypothesis by using $\chi^{2}$ with one degree of freedom (Armitage, 1966).

The methods used to evaluate the significance of an association between a factor and a cause of death were essentially the same, if time of death is taken to be an additional confounding variable and $S_{1}$ represents the number at risk at the beginning of the time period for that stratum.

The ratio of the total observed to the total expected within each level of a factor which is analogous to the standardised mortality ratio is used as an indicator of the relative death rate or relative prevalence of symptoms at the various levels of the factor.

\section{Results}

The sex and age distribution of the three study populations is given in Table 1 and the distribution by smoking groups in Table 2.

Table 1 Sex and age distribution of study population

\begin{tabular}{lllll}
\hline \multicolumn{5}{c}{ Age group (years) } \\
\cline { 2 - 5 } & $45-49$ & $50-54$ & $55-59$ & $60-64$ \\
\hline Men (\%) & $29 \cdot 5$ & $31 \cdot 1$ & $24 \cdot 1$ & $15 \cdot 3$ \\
Women (\%) & $25 \cdot 3$ & $28 \cdot 8$ & $24 \cdot 7$ & $21 \cdot 3$ \\
\hline
\end{tabular}

Table 2 Percentages of 'never smoked', ex-smokers, and current smokers

\begin{tabular}{llll}
\hline & Never smoked & Ex-smokers & Current smokers \\
\hline Men & $19 \cdot 0$ & 28.4 & $52 \cdot 6$ \\
Women & 47.3 & 8.5 & 44.2 \\
\hline
\end{tabular}

Smoker defined as one smoking 5 or more cigarettes a day.

Table 3 demonstrates that, compared with men smokers, women smoked fewer cigarettes, started to smoke later in life, reported inhaling less often, and tended more often to smoke filter cigarettes. These 
differences could not be explained by differences in the age distribution of the sexes. Table 4 reflects the fact that tar yields of cigarettes on the market in 1965-68 were much higher than in 1975-76.

Table 3 Numbers and percentages of current smokers with various smoking characteristics

\begin{tabular}{llrrrr}
\hline & & Men & \multicolumn{3}{c}{ Women } \\
& & No. & \multicolumn{1}{c}{$\%$} & \multicolumn{1}{c}{ No. } & $\%$ \\
\hline Number smoked & $6-17$ & 2348 & $39 \cdot 5$ & 1793 & $54 \cdot 1$ \\
per day & $18-22$ & 2068 & $34 \cdot 8$ & 1172 & $35 \cdot 4$ \\
& $23+$ & 1528 & $25 \cdot 7$ & 348 & $10 \cdot 5$ \\
Type of & Filter & 4117 & $69 \cdot 3$ & 3023 & $91 \cdot 3$ \\
cigarette & Plain & 1518 & $25 \cdot 5$ & 257 & $7 \cdot 8$ \\
& Hand-rolled & 309 & $5 \cdot 2$ & 32 & $1 \cdot 0$ \\
Inhalation & Yes & 5575 & $93 \cdot 8$ & 2854 & $86 \cdot 2$ \\
& No & 369 & $6 \cdot 2$ & 458 & $13 \cdot 8$ \\
Age of starting & $<15$ & 1356 & $22 \cdot 8$ & 338 & $10 \cdot 2$ \\
to smoke & $15-19$ & 3141 & $52 \cdot 8$ & 1538 & $46 \cdot 4$ \\
& $>20$ & 1447 & $24 \cdot 3$ & 1436 & $43 \cdot 4$ \\
\hline
\end{tabular}

Table 4 Percentage of male current smokers smoking brands of different tar level for two study populations

\begin{tabular}{|c|c|c|}
\hline Tar level & $\begin{array}{l}\text { Survey I } \\
(1965-68) \\
\%\end{array}$ & $\begin{array}{l}\text { Survey } 3 \\
(1974-76) \\
\% \\
\end{array}$ \\
\hline Low tar and low to middle & $0 \cdot 0$ & $6 \cdot 7$ \\
\hline $\begin{array}{l}\text { Middle tar (17-22 mg) } \\
\text { Middle to high tar (23-27 mg) } \\
\text { High tar }(28+\mathrm{mg})\end{array}$ & $\begin{array}{r}0 \cdot 3 \\
13 \cdot 3 \\
86 \cdot 4\end{array}$ & $\begin{array}{l}50 \cdot 2 \\
17 \cdot 6 \\
25 \cdot 6\end{array}$ \\
\hline TOTAL ALL TYPES & $100 \cdot 0$ & $\overline{100 \cdot 0}$ \\
\hline Base number of smokers & 1000 & 2486 \\
\hline
\end{tabular}

PREVALENCE OF SYMPTOMS

Table 5 gives, for each of the six symptoms or syndromes studied, the prevalence by smoking group. For all four respiratory symptoms, current smokers had much higher rates than the never smoked group, and ex-smokers had intermediate rates, apart from shortness of breath in women. Men had higher rates for phlegm than women but lower rates for shortness of breath, while bronchitis and wheezing rates were similar in the two sexes. The two cardiovascular symptoms were less clearly related to smoking. Men had higher possible infarction rates than women but slightly lower angina rates.

Table 6 (men) and Table 7 (women) show that for all four respiratory symptoms there was a highly significant positive association with the number of cigarettes smoked which was much stronger for women than for men. There was also a marked relationship in both sexes between the age of starting to smoke and the prevalence of symptoms; people who started to smoke before the age of 15 , taking into account differences in age and number of cigarettes smoked, had prevalence rates almost twice as high as people who started to smoke at the age of 20 or over. Inhalation was less strongly related to prevalence of respiratory symptoms but, even so, inhalers tended to have rates about $30 \%$ higher than non-inhalers. This difference was not always statistically significant, perhaps because of the relatively small number of non-inhalers studied. For these three aspects of smoking behaviour, the trends for cardiovascular symptoms were always in the same direction as those for respiratory symptoms, although the associations were rather weaker and were not always statistically significant.

Smokers of plain cigarettes had a lower prevalence of respiratory symptoms than smokers of filter cigarettes, although in men the differences were fairly small and not always statistically significant; but in women they were always significant. No statistically significant difference in cardiovascular symptoms was seen for either sex, although women who smoked filter cigarettes had a lower prevalence than those who smoked plain ones. Male smokers of hand-rolled cigarettes had prevalence rates for all six symptoms higher than those of smokers of plain or filter tipped cigarettes.

No significant differences by tar level of brand smoked were seen in Survey 1, possibly because at

Table 5 Prevalence of cardiorespiratory symptoms by broad smoking group

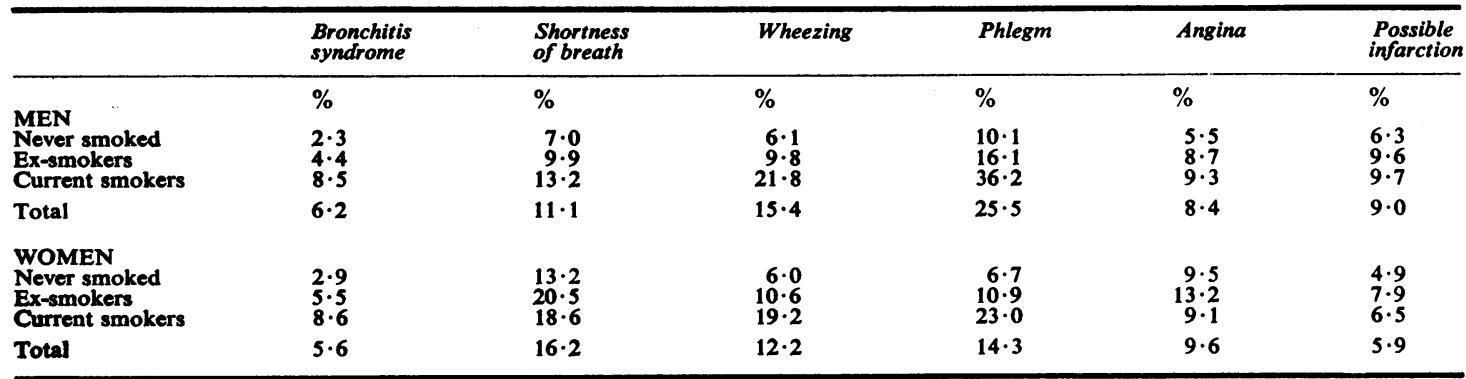


Table 6 Relative symptom prevalence ( $x$ 100) in male current cigarette smokers by number of cigarettes smoked (standardised for age), and by age of starting to smoke, inhalation, and type of cigarette smoked (standardised for age and number of cigarettes smoked $\dagger \dagger$

\begin{tabular}{|c|c|c|c|c|c|c|}
\hline & $\begin{array}{l}\text { Bronchitis } \\
\text { syndrome }\end{array}$ & $\begin{array}{l}\text { Shortness } \\
\text { of breath }\end{array}$ & Wheezing & Phlegm & Angina & $\begin{array}{l}\text { Possible } \\
\text { infarction }\end{array}$ \\
\hline $\begin{array}{l}\text { Number of cigarettes } \\
\text { currently smoked } \\
6-17 \\
18-22 \\
23+ \\
\chi^{2}(2 \mathrm{df})\end{array}$ & $\begin{array}{l}86 \\
93 \\
131 \\
19 \cdot 4 * * * *\end{array}$ & $\begin{array}{l}91 \\
90 \\
127 \\
24 \cdot 2 * * * *\end{array}$ & $\begin{array}{l}80 \\
103 \\
127 \\
60 \cdot 4 * * * *\end{array}$ & $\begin{array}{l}83 \\
102 \\
123 \\
87 \cdot 4 * * * *\end{array}$ & $\begin{array}{l}90 \\
96 \\
121 \\
10 \cdot 3 * * *\end{array}$ & $\begin{array}{c}93 \\
95 \\
119 \\
7 \cdot 8 * *\end{array}$ \\
\hline $\begin{array}{l}\text { Age of starting to smoke } \\
<15 \\
15-19 \\
20+ \\
\chi^{2}(2 \text { df) }\end{array}$ & $\begin{array}{l}148 \\
91 \\
68 \\
50 \cdot 8 * * * *\end{array}$ & $\begin{array}{l}136 \\
95 \\
74 \\
48 \cdot 4^{* * * *}\end{array}$ & $\begin{array}{l}131 \\
96 \\
77 \\
67 \cdot 3^{* * * *}\end{array}$ & $\begin{array}{l}121 \\
101 \\
76 \\
88 \cdot 8 * * * *\end{array}$ & $\begin{array}{l}131 \\
97 \\
78 \\
22 \cdot 6 * * * *\end{array}$ & $\begin{array}{r}111 \\
98 \\
94 \\
2 \cdot 7\end{array}$ \\
\hline $\begin{array}{c}\text { Inhalation } \\
\text { Yes } \\
\text { No } \\
\chi^{2}(1 \text { df })\end{array}$ & $\begin{array}{c}102 \\
70 \\
3 \cdot 6^{*}\end{array}$ & $\begin{array}{c}101 \\
80 \\
2 \cdot 7\end{array}$ & $\begin{array}{l}102 \\
71 \\
9 \cdot 8 * * * *\end{array}$ & $\begin{array}{l}103 \\
62 \\
33 \cdot 1 * * * *\end{array}$ & $\begin{array}{c}102 \\
77 \\
2 \cdot 3\end{array}$ & $\begin{array}{l}102 \\
77 \\
2 \cdot 5\end{array}$ \\
\hline $\begin{array}{l}\text { Type of cigarette } \\
\text { Filter } \\
\text { Plain } \\
\text { Hand-rolled } \\
\chi^{2}(2 \text { df) } \\
\chi^{2} \text { (1 df filter v plain) }\end{array}$ & $\begin{array}{r}96 \\
105 \\
135 \\
3 \cdot 8 \\
1 \cdot 0\end{array}$ & $\begin{array}{l}94 \\
112 \\
125 \\
8 \cdot 4^{* * *} \\
5 \cdot 7 * *\end{array}$ & $\begin{array}{l}95 \\
111 \\
120 \\
12 \cdot 0^{* * *} \\
9 \cdot 3^{* * *}\end{array}$ & $\begin{array}{l}97 \\
106 \\
120 \\
11 \cdot 7 * * * \\
5 \cdot 6 * *\end{array}$ & $\begin{array}{r}103 \\
88 \\
114 \\
3 \cdot 2 \\
2 \cdot 5\end{array}$ & $\begin{array}{r}100 \\
97 \\
126 \\
2 \cdot 2 \\
0 \cdot 1\end{array}$ \\
\hline
\end{tabular}

$* \mathrm{P}<0.1 \quad * * \mathrm{P}<0.05 \quad * * * \mathrm{P}<0.01 \quad * * * \mathrm{P}<0.001$

†ach analysis is also standardised for study

Table 7 Relative symptom prevalence $(x 100)$ in female current cigarette smokers by number of cigarettes smoked (standardised for age), and by age of starting to smoke, inhalation, and type of cigarette smoked (standardised for age and number of cigarettes smoked $) \dagger$

\begin{tabular}{|c|c|c|c|c|c|c|}
\hline & $\begin{array}{l}\text { Bronchitis } \\
\text { syndrome }\end{array}$ & $\begin{array}{l}\text { Shortness } \\
\text { of breath }\end{array}$ & Wheezing & Phlegm & Angina & $\begin{array}{c}\text { Possible } \\
\text { infarction }\end{array}$ \\
\hline $\begin{array}{l}\text { Number of } \\
\text { cigarettes smoked } \\
6-17 \\
18-22 \\
23+ \\
\chi^{2}(2 \mathrm{df})\end{array}$ & $\begin{array}{l}71 \\
104 \\
245 \\
83 \cdot 9 * * * *\end{array}$ & $\begin{array}{l}76 \\
110 \\
192 \\
94 \cdot 0 * * * *\end{array}$ & $\begin{array}{l}77 \\
111 \\
182 \\
81 \cdot 5 * * * *\end{array}$ & $\begin{array}{l}77 \\
114 \\
170 \\
89 \cdot 2 * * * *\end{array}$ & $\begin{array}{l}88 \\
102 \\
158 \\
14 \cdot 3 * * * *\end{array}$ & $\begin{array}{r}94 \\
103 \\
123 \\
1 \cdot 7\end{array}$ \\
\hline $\begin{array}{l}\text { Age of starting to smoke } \\
<15 \\
15-19 \\
20+ \\
\chi^{2}(2 \text { df) }\end{array}$ & $\begin{array}{l}150 \\
117 \\
68 \\
30 \cdot 9 * * * *\end{array}$ & $\begin{array}{l}142 \\
111 \\
77 \\
42 \cdot 1 * * * *\end{array}$ & $\begin{array}{l}136 \\
108 \\
82 \\
27 \cdot 1 * * * * *\end{array}$ & $\begin{array}{l}126 \\
109 \\
83 \\
25 \cdot 9 * * * *\end{array}$ & $\begin{array}{l}165 \\
104 \\
81 \\
21 \cdot 3 * * * *\end{array}$ & $\begin{array}{c}127 \\
104 \\
90 \\
3 \cdot 0\end{array}$ \\
\hline $\begin{array}{l}\text { Inhalation } \\
\text { Yes } \\
\text { No } \\
\chi^{2}(1 \text { df })\end{array}$ & $\begin{array}{r}105 \\
67 \\
5 \cdot 7 * *\end{array}$ & $\begin{array}{l}105 \\
71 \\
10 \cdot 6 * * *\end{array}$ & $\begin{array}{r}103 \\
84 \\
3 \cdot 6^{*}\end{array}$ & $\begin{array}{l}103 \\
83 \\
4 \cdot 6 * *\end{array}$ & $\begin{array}{c}104 \\
75 \\
3 \cdot 6^{*}\end{array}$ & $\begin{array}{r}103 \\
83 \\
1 \cdot 2\end{array}$ \\
\hline $\begin{array}{l}\text { Type of cigarette }+ \\
\text { Filter } \\
\text { Plain } \\
\chi^{2}(1 \text { df })\end{array}$ & $\begin{array}{r}96 \\
151 \\
7 \cdot 7 * * *\end{array}$ & $\begin{array}{r}98 \\
129 \\
5 \cdot 9 * *\end{array}$ & $\begin{array}{l}97 \\
141 \\
11 \cdot 8 * * * *\end{array}$ & $\begin{array}{l}98 \\
124 \\
5 \cdot 0 * *\end{array}$ & $\begin{array}{r}98 \\
129 \\
2 \cdot 4\end{array}$ & $\begin{array}{l}96 \\
140 \\
3 \cdot 3 *\end{array}$ \\
\hline
\end{tabular}

+ Each analysis is also standardised for study

+ Number of female hand-rolled cigarette smokers too small for reliable analysis

Table 8 Relative symptom prevalence $(x, 100)$ in male current cigarette smokers by tar level of brand smoked within type of cigarette smoked (standardised for age and number of cigarettes smoked-Survey 3)

\begin{tabular}{|c|c|c|c|c|c|c|}
\hline & $\begin{array}{l}\text { Bronchitis } \\
\text { syndrome }\end{array}$ & $\begin{array}{l}\text { Shortness } \\
\text { of breath }\end{array}$ & Wheezing & Phlegm & Angina & $\begin{array}{l}\text { Possible } \\
\text { infarction }\end{array}$ \\
\hline $\begin{array}{l}\text { Filter smokers } \\
\text { Low and low to } \\
\text { middle tar } \\
\text { Middle tar } \\
\chi^{2}(1 \text { df })\end{array}$ & $\begin{array}{c}74 \\
104 \\
2 \cdot 2\end{array}$ & $\underset{103}{75}$ & $\begin{array}{r}74 \\
103 \\
3 \cdot 1 * *\end{array}$ & $\begin{array}{c}98 \\
100 \\
0 \cdot 1\end{array}$ & $\begin{array}{c}98 \\
100 \\
0 \cdot 1\end{array}$ & $\begin{array}{c}84 \\
102 \\
0.8\end{array}$ \\
\hline $\begin{array}{l}\text { Plain smokers } \\
\text { Middle tar } \\
\text { Middle to high tar } \\
\text { High tar } \\
\chi^{2}(2 \text { df })\end{array}$ & $\begin{array}{c}96 \\
105 \\
(0)+ \\
2 \cdot 7\end{array}$ & $\begin{array}{c}81 \\
97 \\
(208) \\
6 \cdot 8 * *\end{array}$ & $\begin{array}{l}65 \\
102 \\
168 \\
8 \cdot 3 * *\end{array}$ & $\begin{array}{c}82 \\
103 \\
90 \\
2 \cdot 0\end{array}$ & $\begin{array}{r}69 \\
102 \\
146 \\
1 \cdot 1\end{array}$ & $\begin{array}{c}87 \\
93 \\
(281) \\
11 \cdot 1 * * *\end{array}$ \\
\hline
\end{tabular}

tBracketed relative prevalences are unreliable as based on expected value of less than 5. 
that time there was little difference in tar level of cigarettes on the market. Some differences were, however, seen in Survey 3 (Table 8). Although individual comparisons were often not statistically significant, there was a clear tendency in both filter and plain smokers for smokers of the lower tar cigarettes to have a lower prevalence of symptoms.

\section{MORTALITY}

Table 9 gives the relationship of smoking group to mortality. For men there was a highly significant association with total mortality: the percentage of current smokers who died was more than twice that for the never smoked group, with ex-smokers in an intermediate position. The most marked association for any cause of death was for lung cancer, where current smokers suffered 88 deaths out of 5944 at risk (148 per 10000$)$ with an estimated risk about 30 times higher than that of the never smokers with 1 death out of 2147 ( 4.6 per 10000 ). Positive associations were also seen for a number of other causes of death, although, perhaps because of the small numbers, these were only clearly significant for ischaemic heart disease and for the 'other causes' group.

For women, there was a less clear but still significant excess $(P<0.05)$ of total mortality in current smokers, who suffered more than one and a half times the mortality of those who never smoked. Numbers of deaths in ex-smokers were too small to come to a reliable conclusion, but as for men, their death rate lay between that of 'never' and current smokers. By cause of death, the percentages dying in current smokers were higher than in 'never' smokers for ischaemic heart disease, and for the group of diseases including lung cancer, although the excess was significant only in the latter case.

During the follow-up period, 536 men and 72 women died who were current cigarette smokers at the time of examination. In Table 10, therefore, we looked in detail at the relationship of various aspects of smoking behaviour to total mortality, and, in men, to some of the principal causes of death. Although there was evidence of an increasing total mortality with amount smoked in women smokers (trend on 1 df significant at the $90 \%$ confidence level) this was not so in male smokers, in whom the rates were only $10 \%$ higher for smokers of 23 or more cigarettes a day than for smokers of 6-17 cigarettes a day. There was, however, a significant association with amount smoked for male lung cancer rates.

The age of starting to smoke was not found to be significantly associated with total mortality in either sex or, in men, with any individual cause, although there was a higher mortality in those who started to smoke at younger ages. Combining the results for both sexes gives a trend in mortality which is significant at the $90 \%$ confidence level.

The strongest association seen in Table 10 was between male mortality and inhalation; those who reported inhaling had total death rates almost twice as high as those who did not. This excess, mainly due to an excess ischaemic heart disease mortality rate, was not seen at all in women.

Although the total numbers of male deaths among smokers of filter and plain cigarettes were not insubstantial (323 and 184 respectively), there was not the slightest indication of any difference in overall death rates between smokers of the two different types of cigarette. Nor was any significant

Table 9 Mortality by smoking habits

\begin{tabular}{|c|c|c|c|c|c|c|c|c|}
\hline MEN & \multicolumn{2}{|c|}{$\begin{array}{l}\text { Never smoked } \\
\text { No. } \quad \%\end{array}$} & \multicolumn{2}{|c|}{$\begin{array}{l}\text { Ex-smokers } \\
\text { No. } \%\end{array}$} & \multicolumn{2}{|c|}{$\begin{array}{l}\text { Current smokers } \\
\text { No. } \quad \%\end{array}$} & $\begin{array}{l}\text { All } \\
\text { No. }\end{array}$ & $\%$ \\
\hline $\begin{array}{l}\text { Number at risk } \\
\text { Ischaemic heart disease } \\
\text { Cerebrovascular disease } \\
\text { Other vascular disease } \\
\text { Lung cancer } \\
\text { Chronic bronchitis } \\
\text { Respiratory infection } \\
\text { Other causes } \\
\text { All causes }\end{array}$ & $\begin{array}{r}2147 \\
42 \\
8 \\
0 \\
1 \\
2 \\
2 \\
26 \\
81\end{array}$ & $\begin{array}{r}100.00 \\
1.96 \\
0.37 \\
0.00 \\
0.05 \\
0.09 \\
0.09 \\
1.21 \\
3.77\end{array}$ & $\begin{array}{r}3204 \\
81 \\
15 \\
4 \\
15 \\
3 \\
4 \\
54 \\
176\end{array}$ & $\begin{array}{r}100 \cdot 00 \\
2 \cdot 53 \\
0 \cdot 47 \\
0 \cdot 13 \\
0-47 \\
0 \cdot 09 \\
0 \cdot 13 \\
1 \cdot 69 \\
5 \cdot 49\end{array}$ & $\begin{array}{r}5944 \\
237 \\
33 \\
12 \\
88 \\
23 \\
5 \\
138 \\
536\end{array}$ & $\begin{array}{r}100 \cdot 00 \\
3.99 \\
0 \cdot 56 \\
0 \cdot 20 \\
1.48 \\
0 \cdot 39 \\
0.08 \\
2 \cdot 32 \\
0 \cdot 22\end{array}$ & $\begin{array}{r}11295 \\
360 \\
56 \\
16 \\
104 \\
28 \\
21 \\
11 \\
218 \\
793\end{array}$ & $\begin{array}{r}100 \cdot 00 \\
3 \cdot 19 \\
0.50 \\
0 \cdot 14 \\
0.92 \\
0 \cdot 25 \\
0 \cdot 10 \\
1.93 \\
7.02\end{array}$ \\
\hline WOMEN & & & & & & & & \\
\hline $\begin{array}{l}\text { Number at risk } \\
\text { Ischaemic heart disease } \\
\text { Cerebrovascular and other } \\
\text { vascular disease, lung } \\
\text { cancer, chronic bronchitis, } \\
\text { and respiratory infection }\end{array}$ & $\begin{array}{r}3544 \\
15\end{array}$ & $\begin{array}{r}100 \cdot 00 \\
0.42\end{array}$ & $\begin{array}{r}634 \\
2\end{array}$ & $\begin{array}{r}100 \cdot 00 \\
0 \cdot 79\end{array}$ & $\begin{array}{r}3313 \\
23\end{array}$ & $\begin{array}{r}100.00 \\
0.69\end{array}$ & $\begin{array}{r}7491 \\
43\end{array}$ & $\begin{array}{r}100 \cdot 00 \\
0.57\end{array}$ \\
\hline $\begin{array}{l}\text { Other causes } \\
\text { All causes }\end{array}$ & $\begin{array}{l}30 \\
49\end{array}$ & $\begin{array}{l}0.85 \\
1 \cdot 38\end{array}$ & $\begin{array}{r}2 \\
11\end{array}$ & $\begin{array}{l}0.32 \\
1.74\end{array}$ & $\begin{array}{l}29 \\
72\end{array}$ & $\begin{array}{l}0 \cdot 88 \\
2 \cdot 17\end{array}$ & $\begin{array}{r}61 \\
132\end{array}$ & $\begin{array}{l}0 \cdot 81 \\
2 \cdot 17\end{array}$ \\
\hline
\end{tabular}


Table 10 Relative mortality ( $x$ 100) in current cigarette smokers by number of cigarettes smoked (standardised for age), and by age of starting to smoke, inhalation, and type of cigarette smoked (standardised for age and number smoked) $\dagger$

\begin{tabular}{|c|c|c|c|c|c|c|}
\hline & \multicolumn{5}{|l|}{ Men } & \multirow{2}{*}{ 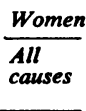 } \\
\hline & $\begin{array}{l}\text { Ischaemic } \\
\text { heart } \\
\text { disease }\end{array}$ & $\begin{array}{l}\text { Cerebrovascular } \\
\text { disease }\end{array}$ & $\begin{array}{l}\text { Lung } \\
\text { cancer }\end{array}$ & $\begin{array}{l}\text { Chronic } \\
\text { bronchitis }\end{array}$ & All causes & \\
\hline $\begin{array}{l}\text { Number of cigarettes smoked } \\
6-17 \\
18-22 \\
23+ \\
\chi^{2}(2 \text { df })\end{array}$ & $\begin{array}{l}102 \\
94 \\
105 \\
0.46\end{array}$ & $\begin{array}{l}77 \\
119 \\
121 \\
1 \cdot 60\end{array}$ & $\begin{array}{l}70 \\
134 \\
118 \\
7 \cdot 90 * *\end{array}$ & $\begin{array}{c}127 \\
80 \\
(67) \dagger \dagger \\
1 \cdot 73\end{array}$ & $\begin{array}{c}94 \\
107 \\
103 \\
1 \cdot 88\end{array}$ & $\begin{array}{l}83 \\
116 \\
149 \\
3 \cdot 65\end{array}$ \\
\hline $\begin{array}{l}\text { Age of starting to smoke } \\
<15 \\
15-19 \\
20+ \\
\chi^{2}(2 \text { df })\end{array}$ & $\begin{array}{r}92 \\
103 \\
102 \\
0 \cdot 50\end{array}$ & $\begin{array}{r}94 \\
119 \\
67 \\
1 \cdot 69\end{array}$ & $\begin{array}{c}113 \\
100 \\
88 \\
0.62\end{array}$ & $\begin{array}{l}123 \\
120 \\
36 \\
3 \cdot 13\end{array}$ & $\begin{array}{l}106 \\
104 \\
87 \\
3 \cdot 30\end{array}$ & $\begin{array}{c}159 \\
85 \\
103 \\
2 \cdot 95\end{array}$ \\
\hline $\begin{array}{l}\text { Inhaling } \\
\text { Yes } \\
\text { No } \\
\chi^{2}(1 \text { df })\end{array}$ & $\begin{array}{l}104 \\
48 \\
5 \cdot 06^{* *}\end{array}$ & $\begin{array}{l}101 \\
(83) \\
0.06\end{array}$ & $\begin{array}{l}101 \\
82 \\
0 \cdot 24\end{array}$ & $\begin{array}{c}98 \\
(125) \\
0.08\end{array}$ & $\begin{array}{l}103 \\
55 \\
9 \cdot 10^{* * *}\end{array}$ & $\begin{array}{c}96 \\
124 \\
0.65\end{array}$ \\
\hline $\begin{array}{l}\text { Type of cigarette } \\
\text { Filter } \\
\text { Plain } \\
\text { Hand-rolled } \\
\chi^{2}(2 \text { df) } \\
\chi^{2} \text { (1 df filter } v \text { plain) }\end{array}$ & $\begin{array}{l}104 \\
99 \\
65 \\
2 \cdot 14 \\
0 \cdot 17\end{array}$ & $\begin{array}{l}121 \\
70 \\
(59) \\
2 \cdot 45 \\
2 \cdot 02\end{array}$ & $\begin{array}{c}89 \\
107 \\
(182) \\
3 \cdot 92 \\
0 \cdot 64\end{array}$ & $\begin{array}{c}81 \\
113 \\
(200) \\
2 \cdot 20 \\
0 \cdot 84\end{array}$ & $\begin{array}{c}101 \\
99 \\
95 \\
0 \cdot 18 \\
0.08\end{array}$ & $\begin{array}{l}102 \\
79 \\
- \\
\overline{0.29}\end{array}$ \\
\hline
\end{tabular}

difference found for any of the causes of death considered in men, or for total mortality in women. We also investigated the possibility of a relationship between mortality and the tar yield of the cigarette. As there was little difference in mortality between filter and plain smokers, and as a relatively small variation in tar yields was observed between brands smoked in Survey 1, which produced the majority of the deaths observed, it was perhaps not to be expected that this analysis would show any significant results. And so it proved.

\section{Discussion}

Our findings on symptom prevalence are in many ways similar to those of Dean et al. (1978) in a representative study of the United Kingdom in 1972. Like us, they found that respiratory symptoms, and to a lesser extent cardiovascular symptoms, were far more prevalent in current smokers and that, among the different groups of smokers, symptom levels were higher in those who smoked heavily and in those who inhaled. They also observed, as we did, that while men had higher phlegm rates than women, the reverse was true for shortness of breath. There were, however, a number of differences between the studies. Firstly, Dean et al. tended to record rather higher rates of wheezing and shortness of breath and lower rates of angina. Secondly, they did not report findings on the age of starting to smoke, with which we were able to demonstrate a marked negative association. Thirdly, and most importantly, while Dean et al. found, with the exception of morning cough, which we did not study, that smokers of filter cigarettes had only slightly and non-significantly lower symptom prevalence rates than smokers of plain cigarettes, we did find a number of substantial differences, especially in women, where smokers of filter cigarettes had, on average, about $30 \%$ lower prevalence rates. We were also able to demonstrate, for some symptoms, that smokers of lower tar cigarettes tended to have lower prevalence rates than smokers of higher tar cigarettes of the same type (filter or plain).

Comparison of our mortality findings with other studies is less straightforward, partly because of the relatively small numbers of deaths observed and partly because of differing definitions of smoking groups. However, there appear to be a number of similarities. For example, our finding that male current cigarette smokers have a death rate from all causes twice that in the never smoked group is broadly comparable with the findings by Doll and Peto (1976), Hammond (1966), Kahn (1966), and Godley (1974). So, too, is our finding of a very large excess risk of lung cancer in current cigarette smokers. The fact that we found no significant association of 'all causes' mortality with the number of cigarettes smoked or the age of starting to smoke, although surprising at first sight, probably reflects the fact that these associations are relatively weak and the number of deaths relatively small. Indeed, the associations we found are not significantly different from those found, where they are available, in the above mentioned four studies. Similarly, though the association between inhalation and total 
male mortality was rather more marked in our study than it was in the studies of either Doll and Peto or Hammond, close examination shows that our finding is within the range of that expected from these larger studies.

Our finding, however, that men smoking filter and plain cigarette have an estimated relative risk of total mortality of 1.02 , with approximate $95 \%$ confidence limits of $0 \cdot 86-1 \cdot 23$, probably does differ significantly from that to be expected from the findings of Dean et al. (1977), who reported relative risks of $0.54,0.66,0.75$, and 0.68 for lung cancer, chronic bronchitis, ischaemic heart disease, and cerebrovascular disease respectively. It is, however, not significantly different from the much smaller difference between filter and plain cigarette smokers' death rates found by Todd et al. (1978), or from that expected from Hammond et al. (1976) in their comparison of death rates in smokers of low, medium and high tar-nicotine cigarettes.

Our study, in general, confirms the associations of smoking with both mortality and prevalence of symptoms that have been found by other workers. However, in regard to the comparison of smokers of filter and plain cigarettes, we have found, compared with previous evidence, a rather greater advantage for filter smokers in terms of symptom prevalence and no advantage in terms of mortality. In view of these discrepancies, and the importance of obtaining reliable information on this comparison and on that between smokers of lower and higher tar cigarettes, more data seem urgently needed.

The studies described were initiated in collaboration with the late Professor D. D. Reid. The studies were supported, on the basis of recommendations made by Professor Reid in his capacity as Chairman of the WHO group on Epidemiological Studies on Ischaemic Heart Disease, by the Scottish Home and Health Department and the Renfrewshire King Edward Memorial Trust. The authors are indebted to Mr. P. N. Lee of the Tobacco Research Council for a major contribution to the planning of the statistical analyses of the study.

Reprints from Professor V. M. Hawthorne, Department of Epidemiology, University of Michigan, Michigan 48109, USA.

\section{References}

Armitage, P. (1966). The chi-square test for heterogeneity of proportions after adjustment for stratification. Journal of the Royal Statistical Society, Series B, 28, 150-163.

Dean, G., Lee, P. N., Todd, G. F., Wicken, A. J., and Sparks, D. N. (1978). Factors related to respiratory and cardiovascular symptoms in the United Kingdom.
Journal of Epidemiology and Community Health, 32, 87-96.

Dean, G., Lee, P. N., Todd, G. F., and Wicken, A. J. (1977). Report on a Second Retrospective Mortality Study in North-East England. Part I. Factors relating to mortality from lung cancer, bronchitis, heart disease and stroke in Cleveland County, with particular emphasis on the relative risks associated with smoking filter and plain cigarettes. Research Paper No. 14. Tobacco Research Council: London.

Doll, R., and Peto, R. (1976). Mortality in relation to smoking. 20 years' observations on male British doctors. British Medical Journal, 2, 1525-1536.

Fulton, M., Adams, W., Lutz, W., and Oliver, M. F. (1978). Regional variations in mortality from ischaemic heart and cerebrovascular disease in Britain. British Heart Journal, 40, 563-568.

Godley, F. H. (1974). Cigarette smoking, social factors and mortality: new estimates from representative national samples. PhD University of Maryland. Xerox University Microfilms: Ann Arbor, Michigan, USA.

Hammond, E. C. (1966). Smoking in relation to the death rates of one million men and women. Monograph No. 19, pp. 127-204. National Cancer Institute.

Hammond, E. C., Garfinkel, L., Seidman, H., and Lew, E. A. (1976). 'Tar' and nicotine contents of cigarette smoke in relation to death rates. Environmental Research, 12, 263-274.

Hawthorne, V. M., Gillis, C. R., Lorimer, A. R., Calvert, F. R., and Walker, T. J. (1969). Blood pressure in a Scottish Island Community. British Medical Journal, $4,651-654$.

Hawthorne, V. M., Gillis, C. R., and Maclean, D. S. (1972). Monitoring health in Scotland. International Journal of Epidemiology, 1, 369-374.

Hawthorne, V. M., Greaves, D. A., and Beevers, D. G. (1975). Community studies of hypertension in Glasgow. In Epidemiology and Control of hypertension, edited by Oglesby Paul. Symposia Specialists Medical Books: Florida.

Kahn, H. A. (1966). The Dorn Study of Smoking and Mortality among US Veterans: Report on Eight and One-Half Years of Observation. Monograph No. 19, pp. 1-126. National Cancer Institute, Bethesda, USA.

Medical Research Council (1966). Questionnaire on respiratory symptoms and instructions for its use. Medical Research Council: London.

Peto, R., and Pike, M. C. (1973). Conservatism of the approximation $\Sigma(0-E)^{2} / E$ in the Logrank test for survival data or tumour incidence data. Biometrics, 29, 579-584.

Rose, G. A., and Blackburn, H. (1968). Cardiovascular survey methods. WHO: Geneva.

Royal College of Physicians (1977). Smoking or Health. The third report from the Royal College of Physicians of London. Pitman Medical: London.

Todd, G. F., Lee, P. N., Lambert, P., and Hunt, B. M. (1978). Four cardiorespiratory symptoms as predictors of mortality. Journal of Epidemiology and Community Health, 32, 267-274.

World Health Organisation (1967). International Classification of Diseases, 8th revision. WHO: Geneva. 